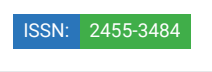

\title{
Physical Literacy and Physical Activity and COVID 19
}

\author{
Manopriya T, Ramesh M and Sheriff DS*
}

Department of Physiology, Chennai, TN, India

Received: 08 January, 2021

Accepted: 22 January, 2021

Published: 23 January, 2021

*Corresponding author: Dhastagir Sultan Sheriff, Department of Physiology, Chennai, TN, India, E-mail: drdsheriff@gmail.com

Keywords: Physical literacy; Physical activity; COVID 19; Mental-health; Obesity

https://www.peertechz.com

\section{Abstract}

COVID 19 has created a new world order. The absence of a specific therapy, uncertainty about the viral transmission of the disease and its mutation, lock down, social distancing have caused mental stress leading to anxiety and depression. The closure of educational institutions and online teaching have made students sedentary. The restricted movement to stay in the house and continuous sitting in front of the computers listening to online teachings have resulted in increased consumption of sugary drinks and fast food. Therefore, physical literacy and physical activity gained importance during the pandemic.

\section{Introduction}

COVID -19 is associated with fear, anxiety and anxiety related disorders. The restricted movement imposed by lock down and social distancing have reduced physical activity. Physical inactivity and sedentary life style are considered as risk factors for cardiovascular disorders. Fear of infection, social stigma and isolation from peers affect the psychology of the students as well as children. The continuous lock down cause mental stress and anxiety. Therefore Physical Activity (PA) with Physical Literacy (PL) will help promote mental health well-being. Physical activity increases blood circulation to the brain and influences Hypothalamic-Pituitary-Adrenal axis (HPA). This in turn may affect different regions of the brain including the limbic system including amygdala, hippocampus and the hippocampus stimulating motivation and causing positive mood response [1-7].

According to the World Health Organization (WHO), physical activity is defined as "any bodily movement produced by skeletal muscles that requires energy expenditure [8]." Physical activity in any form of movement sets a pattern of learning that help to improve the physical, psychological and sporting skills in the participants. To understand the beneficial effects of physical activity, its physiological benefits and psychosocial aspects one need to be literate in physical education. In other words physical literacy delineates the importance of physical activity as well as provides the basis for a coordinated efforts to attain the minimum or standard physical fitness for an adult or a child to learn and exercise.
It includes motivation, confidence, physical competence, knowledge and understanding the value life-long physical activity [9-11]. To attain physical competence one needs to develop the ability to move with balance, co-ordination, dexterity and hand-eye synchronization. Therefore to become a physical literate means "to use the attained knowledge in ethical and just ways. Being literate includes the use of critical and creative thinking a process of conveying information in a multimodal ways of communication, applying knowledge and skills, make connections with and between various contexts $[12,13] . "$

\section{Benefits of physical activity}

A well -coordinated regular physical activity helps to develop physical fitness. Physical fitness is a physiologic state of health that facilitates one to meet the demands of routine physical activity as well as develops the skills to perform better in sports related activities.It also refers to musculoskeletal fitness, cardiovascular health, healthy metabolism and body stature. Physical fitness acts as an indirect measure of physical activity. Physical fitness is defined as a set of attributes that individuals have or can achieve, which is related to their ability to perform physical activity. Physical fitness is often measured through assessing aerobic capacity, muscular strength and muscular endurance. Physical fitness plays an important role in not only maintaining good health but also provides the capacity to undertake fitness tests in military service. For example physical fitness test may include a test of body composition. A physical endurance test like one-minute push 
up and sit test to assess local muscular resistance and 2 to 3 kilometer run to evaluate cardiovascular endurance.

The body composition tests include measure of Body Mass Index (BMI), waist circumference and waist to hip ratio measurements. Other forms of test include multistage fitness tests and tests that will measure the ability of a recruit to join any essential civil or military service depending upon the country [14-16]. There is considerable body of evidence to demonstrate that physical inactivity is a modifiable risk factors for non-communicable diseases like Diabetes, Cardiovascular diseases, obesity, hypertension, cancer and bone disorders is physical inactivity [18-24]. Childhood obesity has become a huge public health problem. It has attracted the attention of health instructors, family physicians and parents during this pandemic. Genetic predisposition, fast food, sugary drinks, sedentary life style, addiction to mobile phones have taken a toll on the health status of children [18-20]. The obese child experience feelings of low esteem, lack of confidence and anxiety. These adverse feelings have an impact on the growth and mental status of the child [21].

A planned physical activity along with routine online classes may help to reduce visceral obesity, increase antiatherogenic HDL cholesterol levels, improve glucose tolerance, and insulin sensitivity. Children with special needs suffer more in the pandemic. It is defined by the federal Maternal and Child Health Bureau as, "those who have or are at increased risk for a chronic physical, developmental, behavioral, or emotional conditions and who also require health and related services of a type or amount beyond that required by children generally [22]." Such parents face multiple barriers to physical activity. The parents had limited finances and inability to pay for physical exercise equipment along with lack of proper community leadership [23]. Most of the barriers reported for physical inactivity are lack of time, lack of transportation, fatigue, health issues and addiction to social media [24-28].

A feeling of physical wellbeing, psychological satisfaction being healthy to attain a good physique, healthy social conditions promote exercise along with environmental factors like peer influence form the best motivators of sustained physical activity [29-32]. Studies have shown that parents' participation in physical activity and community participation promote the physical wellbeing their children and adults [3339].

Physical activity and physical fitness have become the cornerstones of creating a healthy family and community. There is a great awareness among the parents regarding the benefits physical activity in their children. The shift in the attitude to promote physical, and mental well being has led to healthy eating habits and nutrition. Proper training and choice of exercises have created need for physical health instructors among the community to promote health of the child and wellbeing of the community. Trained physiotherapists have become a part and parcel of every sporting activity. Exercise has helped to improve physical activity to attain physical competence to stay fit and healthy, particularly during COVID 19 pandemic.

\section{References}

1. (2020) The Intersection of Covid-19 and mental health. Lancet Infectious Diseases Editorial 1217. Link: https://bit.ly/39YmT0Z

2. Tsigos C, Kyrou I, Kassi E, Chrousos GP (2000) Stress: Endocrine Physiology and Pathophysiology. In: Feingold KR, Anawalt B, Boyce A, et al., editors. Endotext [Internet]. South Dartmouth (MA): MDText.com, Inc. Link: https://bit.ly/39Pvq6a

3. Felipe Barreto S, Brendon P (2019) Current Sports Medicine Reports. 18 299-304

4. Peluso MA, Guerra de Andrade LH (2005) Physical activity and mental health: the association between exercise and mood. Clinics 60: 61-70. Link: https://bit.ly/2NrW91b

5. Antunes R, Frontini R (2020) Physical activity and mental health in Covid-19 times: an editorial. Sleep Med S1389-9457(20)30448-2. Link: https://bit.ly/3sKoNdX

6. Brooks SK, Webster RK, Smith LE, Woodland L, Wessely S, et al. (2020) The psychological impact of quarantine and how to reduce it: rapid review of the evidence. Lancet 395: 912-920. Link: https://bit.ly/2Mditee

7. Geoffrey HT, Robert A, Peter K, Sean A, Greg MM, et al. (2020) Worldwide Effect of COVID-19 on Physical Activity: A Descriptive Study. Annals of Intern Med 173: 767-770. Link: https://bit.ly/3iyuCXo

8. World Health Organization (2015) Obesity and overweight. Link: https://bit.ly/3iAiuFf

9. Whitehead M (2013) Definition of physical literacy and clarification of related ICSSPE Bull J Sport Sci Phys Educ 65: 28-33.

10. Dudley DA (2015) A conceptual model of observed physical literacy. Phys Educ 72: 236-260. Link: https://bit.ly/3p9T2sv

11. Hastie PA, Wallhead TL (2015) Operationalizing physical literacy through sport education. J Sport Health Sci 4: 132-138. Link: https://bit.ly/2Y16BP1

12. Mandigo J, Francis N, Lodewyk K, Lopez R (2009) Physical literacy for educators. Phys Health Educ 75: 27e30

13. Kirk D (2013) Educational value and models-based practice in physical education. Educ Philos Theory 45: 973-986. Link: https://bit.ly/2KDv0r5

14. Operations CoN (2012) OPNAV instruction $6110.1 \mathrm{~J}$. Technical Reports. In 2000 Navy Pentagon, Washington, D.C. 20350-2000: Department of Navy; 2011.Navy BR. RNFT policy and protocols Technical Report. Britian: British Royal Navy.

15. Sargent C, Gebruers C, O'Mahony J (2017) A review of the physiological and psychological health and wellbeing of naval service personnel and the modalities used for monitoring. Military Med Res 4. Link: https://bit.ly/3o5/zh0

16. Appendix iii Regulations relating to the physical examinations of candidates in Indian Police Service.

17. Warburton DE, Nicol CW, Bredin SS (2006) Health benefits of physical activity: the evidence. CMAJ 174: 801-809. Link: https://bit.ly/2MbsYin

18. Paffenbarger RS, Hyde RT, Hsieh CC, Wing AL (1986) Physical activity, other life-style patterns, cardiovascular disease and longevity. Acta Med Scand 711 85-91. Link: https://bit.ly/366ci2S

19. Shephard RJ, Futcher R (1997) Physical activity and cancer: How may protection be maximized? Crit Rev Oncog 8: 219-272. Link: https://bit.ly/3qFol9G

20. Kemmler W, Lauber D, Weineck J, Hensen J, Kalender W, et al. (2004) Benefits of 2 years of intense exercise on bone density, physical fitness, and blood lipids in early postmenopausal osteopenic women: results of the Erlangen 
Fitness Osteoporosis Prevention Study (EFOPS). Arch Intern Med 164: 10841091. Link: https://bit.ly/2NtQOGD

21. Laaksonen DE, Lindstrom J, Lakka TA, Eriksson JG, Niskanen L, et al. (2005) Physical activity in the prevention of type 2 diabetes: the Finnish diabetes prevention study. Diabetes 54: 158-165. Link: https://bit.ly/3p9Uon4

22. Wessel TR, Arant CB, Olson MB, Johnson BD, Reis SE, et al. (2004) Relationship of physical fitness vs body mass index with coronary artery disease and cardiovascular events in women. JAMA 292: 1179-1187. Link https://bit.ly/3sOkmPd

23. Katzmarzyk PT, Church TS, Blair SN (2004) Cardiorespiratory fitness attenuates the effects of the metabolic syndrome on all-cause and cardiovascular disease mortality in men. Arch Intern Med 164: 1092-1097. Link: https://bit.ly/3iBSF7V

24. Sahoo K, Sahoo B, Choudhury AK, Sofi NY, Kumar R, et al. (2015) Childhood obesity: causes and consequences. J Family Med Prim Care 4: 187-192. Link: https://bit.ly/2Y68x9b

25. Karnik S, Kanekar A (2012) Childhood obesity: a global public health crisis. Int J Prev Med 3: 1-7. Link: https://bit.ly/35YpQgL

26. Longo M, Zatterale F, Naderi J, Parrillo L, Formisano P, et al. (2019) Adipose Tissue Dysfunction as Determinant of Obesity-Associated Metabolic Complications. Int J Mol Sci 20: 2358. Link: https://bit.ly/39SdjMR

27. Rankin J, Matthews L, Cobley S, Han A, Sanders R, et al. (2016) Psychological consequences of childhood obesity: psychiatric comorbidity and prevention. Adolesc Health Med Ther 7: 125-146. Link: https://bit.ly/3o35xVr

28. McPherson M, Arango P, Fox H, Lauver C, McManus M, et al. (1998) A new definition of children with special health care needs. Pediatrics 102: 137-140. Link: https://bit.ly/397zQq4

29. Feehan $K$, O'Neil ME, Abdalla D, Fragala-Pinkham M, Kondrad $M$, et al (2012) Factors Influencing Physical Activity in Children and Youth with Special Health Care Needs: A Pilot Study. Int J Pediatr 2012: 583249. Link: https://bit.ly/363gsZ6
30. Booth ML, Owen N, Bauman A, Clavisi O, Leslie E (2000) Social-cognitive and perceived environment influences associated with physical activity in older Australians. Prev Med 31: 15-22. Link: https://bit.ly/2MbFy0T

31. Newson RS, Kemps EB (2007) Factors that promote and prevent exercise engagement in older adults. J Aging Health 19: 470-481. Link: https://bit.ly/3sMhlyV

32. Kosteli MC, Williams SE, Cumming J (2016) Investigating the psychosocial determinants of physical activity in older adults: a qualitative approach. Psycho Health 31: 730-749. Link: https://bit.ly/3c3egoy

33. Sherwood NE, Jeffery RW (2000) The behavioral determinants of exercise: implications for physical activity interventions. Annu Rev Nutr 20: 21-44. Link: https://bit.ly/394M8PF

34. Allender S, Cowburn G, Foster C (2006) Understanding participation in sport and physical activity among children and adults: a review of qualitative studies. Health Educ Res 21: 826-835. Link: https://bit.ly/3pamBdz

35. Brown HE, Schiff A, van Sluijs EM (2015) Engaging families in physical activity research: a family-based focus group study. BMC Public Health 15: 1178. Link: https://bit.ly/3izHtbC

36. Brown HE, Schiff A, van Sluijs EM (2015) Engaging families in physical activity research: a family-based focus group study. BMC Public Health 15: 1178. Link: https://bit.ly/3izHtbC

37. Bentley GF, Goodred JK, Jago R, Sebire SJ, Lucas PJ, et al. (2012) Parents views on child physical activity and their implications for physical activity parenting interventions: a qualitative study. BMC Pediatr 12: 180. Link: https://bit.ly/39YrDnj

38. Jago R, Steeds JK, Bentley GF, Sebire SJ, Lucas PJ, et al. (2012) Designing a physical activity parenting course: parental views on recruitment, content and delivery. BMC Public Health 12: 356. Link: https://bit.ly/3o3fkuV

39. Davison KK, Jurkowski JM, Li K, Kranz S, Lawson HA (2013) A childhood obesity intervention developed by families for families: results from a pilot study. Int J Behav Nutr Phys Act 10: 3. Link: https://bit.ly/3qUTP1h

\section{Discover a bigger Impact and Visibility of your article publication with} Peertechz Publications

\author{
Highlights \\ * Signatory publisher of ORCID \\ * Signatory Publisher of DORA (San Francisco Declaration on Research Assessment) \\ * Articles archived in worlds' renowned service providers such as Portico, CNKI, AGRIS \\ TDNet, Base (Bielefeld University Library), CrossRef, Scilit, J-Gate etc. \\ * Journals indexed in ICMJE, SHERPA/ROMEO, Google Scholar etc. \\ * OAI-PMH (Open Archives Initiative Protocol for Metadata Harvesting) \\ * Dedicated Editorial Board for every journa \\ * Accurate and rapid peer-review process \\ * Increased citations of published articles through promotions \\ * Reduced timeline for article publication \\ Submit your articles and experience a new surge in publication services \\ (https://www.peertechz.com/submission).
}

Peertechz journals wishes everlasting success in your every endeavours.

Copyright: ( 2021 Manopriya T, et al. This is an open-access article distributed under the terms of the Creative Commons Attribution License, which permits unrestricted use, distribution, and reproduction in any medium, provided the original author and source are credited. 